\author{
Anne Baker \\ University of Johannesburg \\ bakerdc@telkomsa.net
}

\title{
Error analysis and language comparison as teaching strategies for German as a foreign language in a South African context
}

\begin{abstract}
Summary
Since 2015 there has been increased protest action by students at South African universities. One of the issues is decolonizing the curriculum. Academics have been re-thinking the curricula of various academic offerings. Recognizing the African heritage of students studying German could be in the form of comparing the first language (L1) of black African learners with German in order to facilitate learning the target language (TL). Specific examples of similarities and differences between German and Zulu are addressed in this article.
\end{abstract}

Keywords: German, Zulu, first language, target language, error analysis

\section{Introduction}

German as a foreign language has been part of the curriculum at South African schools and universities for a long time. It has now come under fire from university students who insist on decolonizing the curriculum, which they consider to be too Eurocentric in its approach, thus perpetuating colonialism and relegating African knowledge bases to a subservient position. One way of addressing this issue is recognizing the first language (L1) of the black African students and the role it plays in acquiring a foreign language. Language comparison is nothing new, but comparing a European language with an African language had only been undertaken in the field of Phonetics by 2003 (Mahlig 2003). Baker (2011) undertook a more general language comparison between German and Zulu, using error analysis as a means to determine which elements needed to be studied more closely. This article relies heavily on the findings of that study.

It is clear that language comparison with the aim to facilitate foreign language learning is not a panacea and may not even be helpful to some learners. Each language learner approaches the new language in a unique way. (Sarter 1991) This study is aimed at teachers and learners who have a specific approach to language learning and the aim is not an exhaustive study of all possible similarities and differences between the L1 and German (TL), but to focus on the most apparent similarities between German and Zulu. The comparison will hopefully stimulate interest in the L1 as well as in the TL. In the South African situation this is particularly important because Zulu is one of the previously marginalized languages. One could even say that due to the hegemony of 
English, all the other official languages are marginalized today. Addressing the issue of decolonizing the Eurocentric basis for foreign language teaching in South Africa by incorporating knowledge of the African languages into the teaching strategy is feasible under certain conditions.

The learners and the teacher have to have meta-knowledge of the L1 if this strategy is going to work. If this strategy is to be implemented in a school setting, ideally the pupils must study the L1 as a school subject and have some knowledge of the structure of the L1 in order to give them autonomy in the learning strategy they employ. Without this knowledge there is no basis for comparison of the L1 with the TL as a language learning strategy.

In a multilingual country like SA, where the majority of the population already speaks several languages before a foreign language is introduced, a whole constellation of languages has to be considered. A Zulu speaking learner would typically grow up in an environment where more than one African language is spoken. When such a child gets to school, he/she probably also knows (some) English, if they attended a nursery school. Some African children go to school with no knowledge of English. The language of teaching and learning in South African public schools is either English or Afrikaans or both, depending on the language policy of the school. Black children typically go to the English schools, so another factor that will have to be taken into consideration when doing a study on foreign language learning among Zulu speaking children, is the quality of their knowledge of English.

\section{Error analysis}

Carrying out and interpreting an error analysis in such a multilingual and multifaceted environment is not straightforward. Köberle (1998) pointed out some advantages of a language teaching method making use of prior language learning experience, which she calls 'interaktionsfokussierendeMethode'. This teaching method includes positive as well as negative transfer, not only from L1, but other languages in the repertoire of the learner as well. Especially in the beginning stages, positive transfer can be a motivating factor. Teaching new information/skills by using what the learner already knows, is a well-known pedagogical principle. It thus stands to reason that an error analysis alone is not sufficient. The teacher must know at least some of the languages in the repertoire of the learners in order to tap into positive as well as negative transfer. In carrying out the error analysis, attention must also be paid to what the learners do well.

An error analysis was carried out at five different schools in South Africa where German is taught as a foreign language (see Baker 2011). The ages of the learners vary between 15-17 years and they have been learning German for 3-5 years. The learners from one school were Zulu L1 speakers who also studied Zulu as a subject at their school. The other learners with a Bantu language as L1 did not. The learners from Germanic L1 backgrounds, Afrikaans and English, showed marked differences in performance, with 
Afrikaans L1 speakers outperforming everyone, but some Bantu L1 speakers outperforming English L1 speakers. These learners (English and Bantu L1) were attending a German school where total immersion was combined with formal grammar teaching and their exposure to German was 5 years as opposed to 3 years of the other learners. The Bantu L1 speakers had no advantage over the English L1 speakers in their class, other than their more extensive prior language learning experience. English L1 speakers are typically monolingual until they get to school and start learning a second language at school. All the others already know at least one other language before they reach school going age. The Afrikaans L1 speakers had the advantage over everyone else because German and Afrikaans are more closely related than German and English, even though all three are Germanic languages. They also typically have more language learning experience than English L1 speakers.

\section{L1 specific errors}

The following errors are totally absent from the work of Afrikaans L1 speakers and only occur in the work of learners with English L1 or English as language of instruction:

1. Orthographical errors that are directly linked to English phonology:

1a. schienen for scheinen 'to shine/appear'

1b. liese for leise 'softly'

1c. veil for weil 'because';

2. $\mathrm{R}$ in the wrong place or omitted:

2a. oner for ohne 'without'

b. kuperlich for körperlich 'bodily'

2c. Gaten for Garten 'garden'

2d. Schweste for Schwester 'sister' and many more. This was particularly striking. Learners who had silent $r$ in their L1 had difficulty, while learners whose L1 does not have silent $\mathrm{r}$ did not.

3. Apostrophe s in Genitive:

3a. Mutti's Jubiläum 'mother's celebration'

3b. Papa's Auto 'father's car'

3c. even some plural forms: Sofa's, Ferrari's.

4. Wrong word order in the Genitive:

4a. die Autorins Verhältnis mit Luchs. 'the author's relationship with Luchs'

5. Some lexico-semantic errors:

5a. schauen for zeigen 'to show'

5 b. halb eins for halb zwei 'half past one'.

Negative transfer from Afrikaans:

6. Sollen instead of werden:

6a. wir sollen Spaß machen 'we will have fun'

6b. ich soll dir ein paar nützliche Tips geben; 'I will give you some helpful tips'. 
7. Wann instead of wenn:

7a. wann du kommst; 'when you come'

7b. wann sie Glück haben 'when they are lucky'.

8. Calques:

8a. Ich suche das Haus für Juni Monat 'I am looking for a house for the month of June

8b. man muss aufpassen für Unfälle 'one must be careful of accidents'

\section{Bantu L1}

Even though all the participants made some errors with personal pronouns, clearly indicating that German is different from the other languages, the Bantu L1 speakers made the most mistakes here. While Afrikaans and English L1 speakers correctly used sex gender identifying pronouns when referring to people, Bantu L1 speakers did not. This error also occurs in the Afrikaans and English usage of Bantu L1 speakers and clearly have a language specific origin. Bantu languages do not distinguish sex gender in noun classification or pronouns. Here are some examples of these errors:

9. Referring to a female person:

9a. Sie entwirft Mode. Vielleicht macht es das Hobby zumBeruf. 'She designs fashion. Perhaps it will make its hobby into an occupation'.

10. Referring to a male person:

10a. Herr Müller ist sehr besonderig. Sie kann... aber sie vergessern seinen Autoschlüssels. 'Mr. Müller is very unusual. She can..., but they forget his car keys'

The errors made by Afrikaans and English L1 learners occur when the pronoun refers to inanimate objects or, to a lesser degree, animals. Here are some examples:

11a. Die Wand - es 'the wall - it'

11b. Die Wohnung - es 'the flat - it'

11c. Holt Waldi und bringt es zu mir 'Fetch Waldi and bring it to me'.

Part of the error analysis that was carried out was a purely quantitative study testing for correctness of the use of definite articles in German. The following table shows the results of this test as applied to Afrikaans L1 learners, English L1 learners and the Bantu L1 learners in the German schools: (Baker 2011)

Table 1. The results for the Africaans L1 learners, English L1 learners and the Bantu L1 learners in the German schools

\begin{tabular}{|c|c|c|c|}
\hline Correct usage & Afrikaans L1 & Bantu L1 & English L1 \\
\hline $80 \%-95 \%$ & $35,30 \%$ & $0,0 \%$ & $0 \%$ \\
\hline $70 \%-79 \%$ & $17,64 \%$ & $40,0 \%$ & $15 \%$ \\
\hline $60 \%-69 \%$ & $17,64 \%$ & $7,5 \%$ & $0 \%$ \\
\hline $50 \%-59 \%$ & $23,53 \%$ & $45,0 \%$ & $8 \%$ \\
\hline Below $50 \%$ & $5,89 \%$ & $7,5 \%$ & $77 \%$ \\
\hline
\end{tabular}


Table 2 shows the results for the Bantu L1 learners from the Zulu school:

Table 2. The results for the Bantu L1 learners from the Zulu school

\begin{tabular}{|c|c|}
\hline Correct usage & Zulu L1 \\
\hline $70 \%-100 \%$ & $0 \%$ \\
\hline $60 \%-69 \%$ & $20 \%$ \\
\hline $50 \%-59 \%$ & $26 \%$ \\
\hline $40 \%-49 \%$ & $40 \%$ \\
\hline Below $40 \%$ & $14 \%$ \\
\hline
\end{tabular}

None of the languages being compared to German here has a system of noun classification along gender lines. Afrikaans and English have no noun classification system at all, but do make a distinction between masculine and feminine in the pronouns when referring to humans. German and Zulu both have a noun classification system, but natural gender is not a distinguishing factor in Zulu at all, not even in the pronouns referring to people. Even though some grammar books characterize the German noun classes as masculine, feminine and neuter, many nouns do not denote anything with natural gender. This can be very confusing. One way of counteracting the gender confusion, is by avoiding the misnomer masculine, feminine, neuter and changing to der-word, die-word, das-word. Some text books already employ the terminology, others do not. The classification of the nouns should be gender neutral, especially in a South African context.

Why would learners from an Afrikaans language background perform so much better than learners from a Zulu language background? Afrikaans has no noun classification system, whereas Zulu has an even more complex noun classification system than German. Why would learners from an English L1 background perform so much worse than both those groups? English is also a Germanic language and very similar to Afrikaans with respect to noun classification and pronoun usage. Why would some Bantu L1 speakers perform so much better than others? Even though large parts of the error analysis show clear trends along L1 lines, this particular test seems to have counter intuitive results. Language comparison alone will not provide the answers. Socio-cultural factors and prior language exposure come into play as well.

Possible explanations for the performance of the different groups of learners are the following:

- Afrikaans is closely related to German. The perceived similarity of the L1 with the TL could have been a motivating factor. Since comprehension precedes acquisition, it can be a powerful motivating factor on an affective as well as a cognitive level.

- The teacher of the Afrikaans speaking learners is not a mother tongue speaker of German and could have put more emphasis on a cognitive approach than German speaking teachers may have done. She may also have encouraged rote learning of vocabulary items, because she knows the difficulties the German noun classification system presents. As De Graaff (1997:166f) points out, explicit instruction and 
explicit knowledge facilitate language learning, because 'noticing' is a prerequisite for further processing and subsequent acquisition.

- Prior language exposure is a facilitating factor as well. Afrikaans speaking children typically learn English before they go to school. Afrikaans speaking people can no longer expect to be able to speak Afrikaans in public settings, so children learn relatively good English skills early in their lives. This language learning experience has a facilitating effect on subsequent language learning. This is borne out by the poor performance of the English monolingual learners. The same applies to the Zulu speaking learners from KwaZulu-Natal who know no Afrikaans and only learn English when they get to school. These learners also grow up in an environment where being exposed to more than one African language, Zulu, before going to school is not a given, because KwaZulu-Natal 's African population is mainly Zulu speaking. The lack of knowledge of Afrikaans could cause them to perceive German to be more foreign than is the case with learners who know at least some Afrikaans and it could impact on their motivation and expectation to succeed.

- Social standing can be a factor in instrumental as well as integrative motivation. English has the highest social standing of all the languages spoken in South Africa. It is the language of economic power and L1 speakers of English will be less motivated to learn a language of perceived limited usefulness in the South African context well, which may account for their high tolerance for errors in the TL. Afrikaans as the perceived 'language of the oppressor' has much lower social status than English or German in the South African context, which may be a contributing factor in the motivation to learn those higher status languages well. African languages have a low social standing. One would expect all the Bantu L1 speakers to be equally motivated to learn the higher status language well. The difference in the type and quality of the teaching the different groups of black learners received, only accounts partially for the big difference in the performance of the black students in the German school and those in the Zulu school in KwaZulu-Natal.

\section{Language difference as a factor}

Significant differences between languages can be an important factor in language learning. Comparing German and Zulu can have a mitigating effect on the perceived insurmountable differences between the L1 and TL. An obvious starting point is the noun classification system that exists in both German and Zulu.

While German only distinguishes 3 noun classes, Zulu distinguishes 17 in total. These include plural forms, because the prefix of each class determines the form of the verb, adjectives, adverbs and pronouns. In German only the definite and indefinite article, personal pronouns and the adjective endings are determined by the classification.

The Zulu noun classification system is a great deal more complicated. Human beings belong to the u- or umu- class and the plural forms are in the o- or aba- class. 
12a. Ubaba - ' father', plural obaba, 'fathers' (Der Vater, die Väter)

12b. Umama - 'mother', plural omama - 'mothers' (die Mutter - die Mütter)

12c. Umuntu -' person', plural abantu - 'persons' (der Mensch - die Menschen)

Pointing out to Zulu speaking learners that the definite article in German corresponds with the noun prefix in Zulu would make them aware of the basic principle. Bringing in the whole array of noun classes in Zulu might be confusing, even to Zulu speaking learners who are doing Zulu as a school subject, so initially limiting it to the human classes might be sufficient. Other noun classes can be introduced later when teaching personal pronouns corresponding with noun class, even when referring to animals and inanimate objects as is the case in German. Contrasting it with English could be helpful, because using English as a reference point for this particular phenomenon is unhelpful.

The agreement of personal pronouns with the noun class a noun belongs to can be taught without making any reference to gender distinctions. As previously indicated, Zulu makes no gender distinction. If this characteristic is applied to German usage of pronouns linked purely to noun classification, some students should be able to apply the principle.

Verb noun congruence is another principle that could be taught to Zulu speaking learners using comparison. Their knowledge of English already facilitates acquisition, but pointing out a similarity with their L1 might add to the knowledge they already have. English is more limited than German and Zulu in this respect, so the added knowledge of Zulu should facilitate acquisition.

13a. Ubab audla inyama. (Der Vater isst das Fleisch.)' Father eats the meat'.

13b. Umama udla inyama. (Die Mutter isst das Fleisch.) 'Mother eats the meat'.

13c. Umuntu udla inyama. (Der Mensch isst das Fleisch.) 'The person eats the meat'.

In the plural the verb prefix referring to people is ba- in Zulu, the form of the verb itself changes in English and German.

13d. Obaba, omama, abantu badla inyama. (Die Väter, Mütter, Menschen essen das Fleisch.) 'The fathers, mothers, people eat the meat'.

Subject verb agreement is present in German, English and Zulu. Creating awareness of exactly how this works in these three languages, pointing out differences as well as similarities, will hopefully improve usage in German.

14a. Ich esse das Fleisch - Ngidla inyama. 'I eat the meat'

14b. Du isst das Fleisch - Udla inyama 'You (singular) eat the meat'

14c. Wir essen das Fleisch - Sidla inyama 'We eat the meat'

14d. Ihr esst das Fleisch - Nidla inyama 'You (plural) eat the meat'

The similarities and differences in the languages that form the language constellation of some South African learners of German pointed out here are the most salient, but by far not the only ones that can aid learners in studying German as a foreign language. More research needs to be done in that particular context, and the other indigenous languages need to be included. Teachers collaborating with researchers is the only way to do this suc- 
cessfully. Decolonizing the curriculum of teaching German as a foreign language in South Africa can only benefit from much more input from many education sectors.

\section{References}

Baker J.M.A. (2011), Apples and pears- German and Zulu. Teaching German as a foreign language with specific reference to Zulu-speaking learners. Saarbrücken, Lamberts Academic Publishing.

De Graaff R. (1997), Differential effects of explicit instruction on second language acquisition. Utrecht, VrijeUniversiteit.

Köberle B. (1998), Positive Interaktion zwischen L2, L3 und L4 und ihre Applikabilität im Fremdsprachenunterricht. In: B. Hufeisen und B. Lindemann, Tertiärsprachen. Theorien, Modelle, Methoden. Tübingen, Stauffenburg.

Mahlig M. (2003), Zulu. In: U. Hirschfeld. Phonetik International: von Afrikaans bisZulu;kontrastive Studien für Deutsch als Fremdsprache. Available at http://www.heidrun-popp.de. Accessed in August 2004.

Sarter H. (1991), Sprache, Spracherwerb, Kultur. Das Beispiel der Migrantenkinder in Frankreich. Tüngen, GüntherNarr. 